\title{
Effects of Different Soil Management on the Chemical Parameters and Enzyme Activities of the Soil in a Long-Time Viticultural Trial. Part I: The Lanes
}

\author{
Klaus SCHALLER*) \\ Geisenheim University, Department of Applied Biology, P.O.B. 1154, D-65366 Geisenheim, Germany \\ *)Corresponding author, e-mail: klaus.schaller@hs-gm.de
}

BulletinUASVM Horticulture 73(2) / 2016

Print ISSN 1843-5254, Electronic ISSN 1843-5394

DOI:10.15835/buasvmcn-hort:12152

\begin{abstract}
Soil tillage and management concepts are basic operations in viticulture because with both interventions the viticultural ecosystem can shift to a stable and sustainable production system or in the worst case will partly loose its productivity and getting harmful for surrounding environments. Modern viticulture should therefore focus on stable yield and qualities but also on soil quality and environmental sound production systems.

In a long term test 5 different tillage systems (control, permanent grass sod, marginal sod, extensive and intensive shallow tillage) were investigated. In the grassed plots was demonstrated that the macro-nutrients $\mathrm{P}$, $\mathrm{K}$, and Mg changed their availability: inorganic $\mathrm{P}$ was reduced, $\mathrm{K}$ and $\mathrm{Mg}$ got in a new balance, favoring a better nutritional status of grapevines. Micronutrients availability was increased especially $\mathrm{Fe}$ and $\mathrm{Mn}$ which are essential on calcareous production sites. Plots with permanent grass cover showed a significant increase in total C. During the test period of 20 years, the permanent grass stored in an average $\approx 3.3 \mathrm{t} \mathrm{CO}_{2} \mathrm{x} \mathrm{ha}^{-1} \mathrm{x} \mathrm{a}^{-1}$. Neither the control plot nor the tilled ones could significantly increase the soils' C stock. Biological activity was determined with enzyme assays. Glucosidases are significantly higher in grassed plots and extensive tilling; same is true for phosphatases. Urease is also the highest in grassed plots and extensive tilling. A strong and significant stratification with soil depth could be demonstrated for all analyzed parameters.
\end{abstract}

Keywords: carbon enrichment, grass cover, rotary tilling, soil enzymes, soil tillage

\section{INTRODUCTION}

Soil tillage moves more and more in the focus of agriculturists and environmentalists as well. The current discussion about glyphosate which focuses only on pesticide aspects of this agent and does not consider soil erosion which can be drastically reduced in combination with specific tillage methods. Loss of soil organic matter resulting from extensive and/or wrong tillage systems as well as erosion reduces the fitness of the soil's and their productivity. There arises a need to assess soil quality in the course of development of sustainable viticulture systems. Despite the possible inputs of mineral fertilizers and pesticides, the basic and unique interest in sustainable soil systems is its capability to cycle nutrients and C (Warkentin 1995; Dick 1992)

In viticulture exists an exceptional awareness about the value of the soil because in the most of the European countries grapevines are cultivated in sloped vineyards. For climatological reasons, the rows are laid out in the slope line. In that 
case erosion risks are extremely high. Therefore, already in the late $50 \mathrm{~s}$ of the last century test trials were laid out in order to investigate the influence of different soil tillage methods to save soils in these sloping landscapes. Conflicts also exist between soil conservation and viticulture issues: implementing systems with a permanent grass sod lead to additional water consumption by the grasses which will induce a severe concurrence for the grapevines, resulting in some years in lower yields and quality (Steinberg, 1979). Soil tillage was always in the focus of discussions in viticulture because on one hand side all are aware of the importance of sound soils for production and, on the other hand chosen systems should not affect in any case the viticultural system especially the yield and quality.

\section{MATERIALS AND METHODS}

\section{Test plots}

The plots are located in the site "Geisenheimer Mäuerchen" (49.986867 ${ }^{\circ} \mathrm{N} ; 7.949713^{\circ} \mathrm{E}, 110 \mathrm{~m}$ a.s.l.). Slope is $4.5^{\circ}$ and soil a clayey loess derived loam.

All plots are planted with Riesling (clone 239), grafted on $26 \mathrm{G}$. Planting density is $1.50 \mathrm{~m} \times 2.00$ $\mathrm{m}$; planting date 1958. Seven years after planting the tillage trial was established in 1965 with 4 replicates for every tillage system.

1. Control (C): Soil tillage as required with rototiller or rotary cultivator, ridged up in autumn (15 cm deep). Operations were done in average 5 times/growing season.

2. Permanent grass cover (PG): The grass sod was at first installed with Lolium perenne. Depending on the weather the sod was mechanically mulched in average 6 times per year. No mechanical tillage occurred since 1965. According to Wienhaus (1981) L. perenne was replaced by Festuca arundinacea. In the row soil was ridged up in autumn.

3. Natural grass sod (NG): Since 1965 no soil tillage; only mulching has been done to cut down natural growth; in an average 6 times per year. It is now a mixture of $F$. arundinacea, Poa pratensis, Festuca rubra and some other bunch type grasses.

4. Extensive cultivation (EC): Mechanical tilling was reduced to as less as necessary. Normally, 3 cultivations during the growing season and ridge up in the row in autumn were made.
5. Intensive shallow cultivation (IC): Shallow, mechanical tilling in an average of 6 times per year and ridge up in the row in autumn.

$\underline{\text { Soil analysis }}$

In every plot soil samples were taken from the lane. In the lane, sampling was done from 0-40 $\mathrm{cm}$ depth with $10 \mathrm{~cm}$ increments. Samples were air dried, mortared and sieved $(<2 \mathrm{~mm})$ and the following soil chemical parameters were analyzed: total-C, total- $\mathrm{N}, \mathrm{pH}, \mathrm{P}$ and $\mathrm{K}$ according the VDLUFA methods and the microelements $\mathrm{Fe}, \mathrm{Zn}, \mathrm{Mn}$ and $\mathrm{Cu}$ according to Lindsey and Norvell (1978).

Soil enzyme activities: Neutral and alkaline phosphatase activity according to Tabatabai and Bremner (1969) were analyzed. $\alpha$-glucosidase and $\beta$-glucosidase were examined according to Hayano (1973) and urease activity according to Bremner and Douglas (1971).

All results were analyzed after testing for homogeneity with One way and Two way ANOVA respectively.

\section{RESULTS AND DISCUSSIONS}

\section{Soil chemical parameters}

Table 1 presents all the analyzed basic parameters $\mathrm{pH}, \mathrm{C}$ and $\mathrm{N}$ content for all treatments. An important key feature is soil $\mathrm{pH}$ because it is a fine indicator for nutrient mobility as well as soil fertility. The initial pH is represented in the control plot with 7.28. Horizontal comparison in the 30$40 \mathrm{~cm}$ layer for all treatments shows no significant differences. In the upper layer a differentiation in $\mathrm{pH}$ between treatments is obvious: $\mathrm{PG}$ has the lowest values in the layers $0-10,10-20$ and 20$30 \mathrm{~cm}$, which were all significant against C, NG, $\mathrm{EC}$, and IC. The vertical $\mathrm{pH}$ changes in the diverse treatments show that $\mathrm{pH}$ is affected only in the upper soil layer with exception of PG where a decrease is observed down to $30 \mathrm{~cm}$. On one hand side this decrease may be positive for the mobility of minor elements as well as phosphorus. In contrast to these effects, lowering of $\mathrm{pH}$ in such soils rich in clay, soil structure and tilth may be negatively influenced on the long run.

Total C: Total soil carbon content is a valuable indicator of soil quality and overall soil fertility. Overall production systems (conventional, organic, and bio-dynamic) are recommended to increase soil organic matter because of their 
Tab. 1: Influence of different tillage systems on general soil chemical parameters

\begin{tabular}{cccccc}
\hline Soil depth (cm) & $\begin{array}{c}\text { Control } \\
{[\mathbf{C}]}\end{array}$ & $\begin{array}{c}\text { Grass sod } \\
{[\mathbf{P G}]}\end{array}$ & $\begin{array}{c}\text { Natural grass sod Extensive cultivation } \\
{[\mathbf{N G}]}\end{array}$ & $\begin{array}{c}\text { Intensive shallow } \\
{[\mathbf{E C}]}\end{array}$ \\
\hline & & \multicolumn{5}{c}{$\mathbf{p H}$} & \\
\hline $00-10$ & $7.28 \mathrm{~A}^{\mathrm{a}} \mathrm{a}^{\mathrm{b}}$ & $6.73 \mathrm{~A} \mathrm{~b}$ & $7.10 \mathrm{~A} \mathrm{a}$ & $7.20 \mathrm{~A} \mathrm{a}$ & $7.05 \mathrm{~A} \mathrm{a}$ \\
\hline $10-20$ & $7.28 \mathrm{~A} \mathrm{a}$ & $7.08 \mathrm{~B} \mathrm{~b}$ & $7.23 \mathrm{~B} \mathrm{a}$ & $7.30 \mathrm{~B} \mathrm{a}$ & $7.15 \mathrm{AB} \mathrm{cb}$ \\
\hline $20-30$ & $7.28 \mathrm{~A} \mathrm{a}$ & $7.13 \mathrm{BC} \mathrm{b}$ & $7.28 \mathrm{~B} \mathrm{a}$ & $7.35 \mathrm{~B} \mathrm{a}$ & $7.23 \mathrm{~B} \mathrm{a}$ \\
\hline $30-40$ & $7.28 \mathrm{~A} \mathrm{a}$ & $7.25 \mathrm{C} \mathrm{a}$ & $7.28 \mathrm{~B} \mathrm{a}$ & $7.35 \mathrm{~B} \mathrm{a}$ & $7.23 \mathrm{~B} \mathrm{a}$ \\
\hline & & & Total C $(\%)$ & \\
\hline $00-10$ & $1.51 \mathrm{~A} \mathrm{a}$ & $2.48 \mathrm{~A} \mathrm{~b}$ & $1.94 \mathrm{~A} \mathrm{c}$ & $1.82 \mathrm{~A} \mathrm{ac}$ & $1.45 \mathrm{~A} \mathrm{a}$ \\
\hline $10-20$ & $0.94 \mathrm{~B} \mathrm{a}$ & $0.86 \mathrm{~B} \mathrm{~b}$ & $0.96 \mathrm{~B} \mathrm{ac}$ & $1.04 \mathrm{~B} \mathrm{~d}$ & $0.90 \mathrm{~B} \mathrm{a}$ \\
\hline $20-30$ & $0.74 \mathrm{C} \mathrm{a}$ & $0.78 \mathrm{C} \mathrm{a}$ & $0.87 \mathrm{C} \mathrm{b}$ & $0.81 \mathrm{C} \mathrm{b}$ & $0.76 \mathrm{C} \mathrm{a}$ \\
\hline $30-40$ & $0.71 \mathrm{C} \mathrm{a}$ & $0.66 \mathrm{D} \mathrm{b}$ & $0.77 \mathrm{C} \mathrm{c}$ & $0.66 \mathrm{D} \mathrm{b}$ & $0.73 \mathrm{C} \mathrm{a}$ \\
\hline & & & Total N (\%) & \\
\hline $00-10$ & $0.110 \mathrm{~A} \mathrm{a}$ & $0.156 \mathrm{~A} \mathrm{~b}$ & $0.145 \mathrm{~A} \mathrm{~b}$ & $0.143 \mathrm{~A} \mathrm{~b}$ & $0.119 \mathrm{~A} \mathrm{a}$ \\
\hline $10-20$ & $0.088 \mathrm{~B} \mathrm{a}$ & $0.096 \mathrm{~B} \mathrm{~b}$ & $0.098 \mathrm{~B} \mathrm{~b}$ & $0.095 \mathrm{~B} \mathrm{~b}$ & $0.091 \mathrm{~B} \mathrm{a}$ \\
\hline $20-30$ & $0.079 \mathrm{~B} \mathrm{a}$ & $0.086 \mathrm{BC} \mathrm{b}$ & $0.091 \mathrm{~B} \mathrm{c}$ & $0.084 \mathrm{BC} \mathrm{b}$ & $0.086 \mathrm{~B} \mathrm{~b}$ \\
\hline $30-40$ & $0.082 \mathrm{~B} \mathrm{a}$ & $0.078 \mathrm{C} \mathrm{b}$ & $0.090 \mathrm{~B} \mathrm{c}$ & $0.074 \mathrm{C} \mathrm{b}$ & $0.079 \mathrm{~B} \mathrm{~b}$ \\
\hline
\end{tabular}

alues within a row followed by different lower case letters are significantly different (LSD $p \leq 0.05$ ).

${ }^{b}$ Values within a column followed by different upper case letters are significantly different (LSD $p \leq 0.05$ ).

Tab. 1a: $\mathrm{C}$ accumulation in vineyard's soil as a function of different soil tillage systems $\left(\mathrm{kg} \mathrm{C} / \mathrm{m}^{2}\right)$

\begin{tabular}{|c|c|c|c|c|c|}
\hline Soil depth (cm) & $\begin{array}{l}\text { Control } \\
\text { [C] }\end{array}$ & $\begin{array}{l}\text { Grass sod } \\
\text { [PG] }\end{array}$ & $\begin{array}{c}\text { Natural grass } \\
\text { sod } \\
{[\mathrm{NG}]} \\
\end{array}$ & $\begin{array}{c}\text { Extensive cultivation } \\
\text { [EC] }\end{array}$ & $\begin{array}{c}\text { Intensive shallow } \\
\text { [IC] }\end{array}$ \\
\hline \multicolumn{6}{|c|}{$\mathrm{kg} \mathrm{C} / \mathrm{m}^{2}$} \\
\hline $00-10$ & $1.428 \mathrm{Aa}$ & $3.257 \mathrm{Ab}$ & $2.753 \mathrm{Ac}$ & $2.211 \mathrm{Ac}$ & $1.767 \mathrm{Aa}$ \\
\hline $10-20$ & $1.218 \mathrm{Ba}$ & $1.273 \mathrm{Bb}$ & $1.471 \mathrm{Bc}$ & $1.339 \mathrm{Bc}$ & $1.132 \mathrm{Ba}$ \\
\hline$\sum 00-20$ & $2.646 \mathrm{a}$ & $4.530 \mathrm{~b}$ & $3.224 \mathrm{c}$ & $3.550 \mathrm{c}$ & $2.889 \mathrm{a}$ \\
\hline
\end{tabular}

positive effects on soils as well as on product quality. The vertical distribution of C (Tab. 1) in the different treatments reveals that in the upper two layers $(0-10$ and $10-20 \mathrm{~cm}) \mathrm{C}$ values are the highest where both layers differ significantly. Towards the deeper layers no further significant differences exist. Comparing the $\mathrm{C}$ concentrations horizontally it can be seen that the highest $\mathrm{C}$ enrichment occurs in PG, NG, and EC; none or only restrictive cultivation techniques favors the buildup of a substantial C stock. Towards deeper soil layers the differentiation between treatments is not as clear as in the upper ones. This is also a consequence of the former deep ploughing before the plantation was established.
Total N: Total $\mathrm{N}$ follows more or less the same pattern as total C. Remarkable is the high concentrations in $\mathrm{PG}$ and $\mathrm{NG}$ as well as in $\mathrm{EC}$ in the upper two layers. The vertical distribution shows that $\mathrm{N}$ is preferentially stored in $0-20 \mathrm{~cm}$ soil depth.

In Table 1a the total $\mathrm{C}$ accumulation $\left(\mathrm{kg} \mathrm{C} \mathrm{m}^{-2}\right)$ is shown dependent on the different soil tillage systems for the two upper layers 0-10 and 10-20 $\mathrm{cm}$ and with special consideration of soil density. The vertical comparison shows that in every treatment both soil depths differ significantly. There exists a real decreasing gradient with soil depth.

The horizontal comparison reveals that PG and NG differ significantly from each other and 
Tab. 2: Influence of different tillage systems on plant available $\mathrm{P}, \mathrm{K}$, and $\mathrm{Mg}$ (ppm)

\begin{tabular}{|c|c|c|c|c|c|}
\hline Soil depth (cm) & $\begin{array}{c}\text { Control } \\
{[\mathrm{C}]}\end{array}$ & $\begin{array}{c}\text { Grass sod } \\
{[\mathrm{PG}]}\end{array}$ & $\begin{array}{c}\text { Natural grass sod } \\
{[\mathrm{NG}]}\end{array}$ & $\begin{array}{c}\text { Extensive cultivation } \\
\text { [EC] }\end{array}$ & $\begin{array}{c}\text { Intensive shallow } \\
\text { [IC] }\end{array}$ \\
\hline \multicolumn{6}{|c|}{$\mathbf{P}$} \\
\hline $00-10$ & $537 \mathrm{~A}^{\mathrm{a}} \mathrm{a}^{\mathrm{b}}$ & $372 \mathrm{Ab}$ & $387 \mathrm{Ab}$ & $391 \mathrm{Ab}$ & $458 \mathrm{Ac}$ \\
\hline $10-20$ & $463 \mathrm{~B} \mathrm{a}$ & $367 \mathrm{Ab}$ & $369 \mathrm{Ab}$ & $389 \mathrm{~A} \mathrm{~b}$ & $451 \mathrm{~A} \mathrm{a}$ \\
\hline $20-30$ & $410 \mathrm{~B} \mathrm{a}$ & $379 \mathrm{Ab}$ & $396 \mathrm{Ab}$ & $359 \mathrm{~A} \mathrm{~b}$ & $441 \mathrm{Ac}$ \\
\hline $30-40$ & $338 \mathrm{Ca}$ & $314 \mathrm{~B}$ ac & $354 \mathrm{~B} \mathrm{ab}$ & 298 B c & $384 \mathrm{~B} \mathrm{~d}$ \\
\hline \multicolumn{6}{|c|}{$\mathbf{K}$} \\
\hline $00-10$ & $500 \mathrm{~A} \mathrm{a}$ & $401 \mathrm{~A} \mathrm{c}$ & $379 \mathrm{Ac}$ & $598 \mathrm{~A} \mathrm{~b}$ & $502 \mathrm{~A} \mathrm{a}$ \\
\hline $10-20$ & $342 \mathrm{~B} \mathrm{a}$ & $325 \mathrm{~B} \mathrm{a}$ & $318 \mathrm{~B} \mathrm{a}$ & $392 \mathrm{~B} \mathrm{~b}$ & $373 \mathrm{~B} \mathrm{~b}$ \\
\hline $20-30$ & $313 \mathrm{~B} \mathrm{a}$ & $318 \mathrm{~B} \mathrm{a}$ & $333 \mathrm{~B} \mathrm{~b}$ & $296 \mathrm{~B} \mathrm{c}$ & $320 \mathrm{~B} \mathrm{a}$ \\
\hline $30-40$ & $331 \mathrm{~B} \mathrm{a}$ & $320 \mathrm{~B} \mathrm{a}$ & $331 \mathrm{~B} \mathrm{a}$ & $268 \mathrm{~B} \mathrm{~b}$ & $325 \mathrm{~B} \mathrm{a}$ \\
\hline \multicolumn{6}{|c|}{ Mg } \\
\hline $00-10$ & $86 \mathrm{Aa}$ & $123 \mathrm{~A} \mathrm{~b}$ & $82 \mathrm{Aa}$ & $104 \mathrm{~A} \mathrm{c}$ & $82 \mathrm{~A} \mathrm{a}$ \\
\hline $10-20$ & $71 \mathrm{~B} \mathrm{a}$ & $79 \mathrm{~B} \mathrm{a}$ & $58 \mathrm{~B} \mathrm{~b}$ & $91 \mathrm{Ac}$ & $58 \mathrm{~B} \mathrm{~b}$ \\
\hline $20-30$ & $68 \mathrm{~B} \mathrm{a}$ & $61 \mathrm{~B} \mathrm{a}$ & $51 \mathrm{~B} \mathrm{~b}$ & $62 \mathrm{~B} \mathrm{a}$ & $51 \mathrm{~B} \mathrm{~b}$ \\
\hline $30-40$ & $68 \mathrm{~B} \mathrm{a}$ & $57 \mathrm{~B} \mathrm{~b}$ & $48 \mathrm{~B} \mathrm{c}$ & $51 \mathrm{~B} \mathrm{~b}$ & $48 \mathrm{~B} \mathrm{c}$ \\
\hline
\end{tabular}

avalues within a row followed by different lower case letters are significantly different (LSD $\mathrm{p} \leq 0.05$ ).

${ }^{b}$ Values within a column followed by different upper case letters are significantly different (LSD $p \leq 0.05$ ).

the control as well as IC. NG and EC are different. A similar pattern is found in the layer $10-20 \mathrm{~cm}$. The sum of total $\mathrm{C}$ accumulated in $0-20 \mathrm{~cm}$ shows that $\mathrm{PG}$ has the highest potential to stock $\mathrm{C}$ followed by EC and NG; both without significant differences, taking into account the test duration of 16 years PG stored $0.117 \mathrm{~kg} \mathrm{C} \mathrm{x} \mathrm{m}^{-2} \mathrm{x} \mathrm{a}^{-1}$ in comparison to the control plot which corresponds to $3.32 \mathrm{t} \mathrm{CO}_{2}$ $\mathrm{x} h \mathrm{~h}^{-1} \mathrm{x} \mathrm{a}^{-1}$.

\section{Macronutrients (Table 2)}

Soil tillage and especially the use of grass sods, annual and permanent grass with and without legumes will exert a strong influence on nutrients and their dynamics. In Table 2 the most important macronutrients $(\mathrm{P}, \mathrm{K}$, and $\mathrm{Mg}$ ) are listed. According to the testing methods slightly soluble and parts of the immobile reservoir are determined. Phosphorus is a nutrient which is more or less immobile which can be seen in Table 2 . The vertical comparison shows that the upper three layers of all treatments do not differ significantly in their $\mathrm{P}$ concentration. Only the fourth layer has lower $\mathrm{P}$ contents. This fact indicates that $P$ is very immobile and also indicates that fertilizer $\mathrm{P}$ is mixed in the normal plough layer; a further movement is not detectable. In contrast, the horizontal comparison reveals some interesting aspects. The lowest $\mathrm{P}$ values in the $0-10 \mathrm{~cm}$ layer are found in $P G$ and NG, whereas C and IC are highest. These low $P$ values may indicate that parts of the $P$ reservoir are stored as organic $\mathrm{P}$, which cannot be detected with the methodology in use. The reduction is significant in PG, NG and EC; same sequence can be stated for the layers $10-20$ and $20-30 \mathrm{~cm}$.

Potassium behaves similar to P. It is significantly lower in PG and NG. The vertical distribution in the analyzed treatments allows the assumption that the movement of $\mathrm{K}$ to deeper layers is restricted by the high clay content of the soil. On the other hand in PG and NG and K contents are significantly lower in comparison to $\mathrm{C}, \mathrm{EC}$ and IC. That is also true for the layers $10-20$ and $20-30$ $\mathrm{cm}$. A possible explanation for this may be that the grasses absorb preferentially monovalent cations in comparison to divalent ones, which may lead to a reduction of exchangeable soil $\mathrm{K}$. A similar stratification is also found for magnesium. The vertical comparison shows an accumulation in the upper layer and a significant higher amount in PG and EC. Normally $\mathrm{Mg}$ is higher in deeper layers but the leaching is probably restricted by the low rainfall rates in that region. A positive effect of this nutrient distribution is that in the PG plots neither $\mathrm{Mg}$ deficiency symptoms nor bunch stem necrosis were observed. 
Tab. 3: Influence of different tillage systems on plant available micronutrients $\mathrm{Fe}, \mathrm{Zn}$ and $\mathrm{Mn}$ (ppm)

\begin{tabular}{|c|c|c|c|c|c|}
\hline Soil depth (cm) & $\begin{array}{c}\text { Control } \\
\text { [C] }\end{array}$ & $\begin{array}{c}\text { Grass sod } \\
\text { [PG] }\end{array}$ & $\begin{array}{c}\text { Natural grass sod } \\
{[\mathrm{NG}]}\end{array}$ & $\begin{array}{c}\text { Extensive cultivation } \\
\text { [EC] }\end{array}$ & $\begin{array}{c}\text { Intensive shallow } \\
\text { [IC] }\end{array}$ \\
\hline \multicolumn{6}{|c|}{$\mathbf{F e}$} \\
\hline $00-10$ & $6.2 \mathrm{~A}^{\mathrm{a}} \mathrm{a}^{\mathrm{b}}$ & $19.4 \mathrm{~A} \mathrm{~b}$ & $14.7 \mathrm{~A} \mathrm{bc}$ & $10.6 \mathrm{~A} \mathrm{ac}$ & $11.6 \mathrm{~A} \mathrm{c}$ \\
\hline $10-20$ & $4.6 \mathrm{~B} \mathrm{a}$ & $7.1 \mathrm{~B} \mathrm{bc}$ & $8.7 \mathrm{~B} \mathrm{~b}$ & $6.9 \mathrm{~B} \mathrm{c}$ & $8.7 \mathrm{~B} \mathrm{~b}$ \\
\hline $20-30$ & $3.6 \mathrm{~B} \mathrm{a}$ & $6.0 \mathrm{~B} \mathrm{~b}$ & $8.2 \mathrm{~B} \mathrm{c}$ & $5.6 \mathrm{~B} \mathrm{~b}$ & $7.7 \mathrm{~B} \mathrm{~d}$ \\
\hline $30-40$ & $3.6 \mathrm{~B} \mathrm{a}$ & $4.8 \mathrm{~B} \mathrm{ac}$ & $6.9 \mathrm{~B} \mathrm{~b}$ & $5.1 \mathrm{~B} \mathrm{c}$ & $6.9 \mathrm{~B} \mathrm{~b}$ \\
\hline \multicolumn{6}{|c|}{$\mathrm{Zn}$} \\
\hline $00-10$ & $8.1 \mathrm{~A} \mathrm{a}$ & $11.7 \mathrm{~A} \mathrm{~b}$ & $10.5 \mathrm{~A} \mathrm{~b}$ & $11.1 \mathrm{~A} \mathrm{~b}$ & $11.1 \mathrm{~A} \mathrm{~b}$ \\
\hline $10-20$ & $5.8 \mathrm{~B} \mathrm{a}$ & $6.5 \mathrm{~B} \mathrm{a}$ & $5.9 \mathrm{~B} \mathrm{a}$ & $8.2 \mathrm{~B} \mathrm{~b}$ & $7.2 \mathrm{BC} \mathrm{c}$ \\
\hline $20-30$ & $4.3 \mathrm{BC} \mathrm{a}$ & $5.1 \mathrm{~B} \mathrm{~b}$ & $5.1 \mathrm{~B} \mathrm{~b}$ & $5.0 \mathrm{C} \mathrm{b}$ & $5.7 \mathrm{~B} \mathrm{c}$ \\
\hline $30-40$ & $3.1 \mathrm{C} \mathrm{a}$ & $3.9 \mathrm{~B} \mathrm{~b}$ & $4.3 \mathrm{~B} \mathrm{bc}$ & $4.4 \mathrm{C} \mathrm{bc}$ & $4.6 \mathrm{BC} \mathrm{dc}$ \\
\hline \multicolumn{6}{|c|}{ Mn } \\
\hline $00-10$ & $2.3 \mathrm{~A} \mathrm{a}$ & $7.1 \mathrm{~A} \mathrm{~b}$ & $5.8 \mathrm{~A} \mathrm{bc}$ & $4.5 \mathrm{~A} \mathrm{c}$ & $5.1 \mathrm{Ac}$ \\
\hline $10-20$ & $2.2 \mathrm{~A} \mathrm{a}$ & $2.3 \mathrm{~B} \mathrm{a}$ & $3.9 \mathrm{~B} \mathrm{~b}$ & $2.7 \mathrm{~B} \mathrm{a}$ & $3.9 \mathrm{~B} \mathrm{~b}$ \\
\hline $20-30$ & $1.6 \mathrm{BC} \mathrm{a}$ & $2.1 \mathrm{~B} \mathrm{a}$ & $4.0 \mathrm{~B} \mathrm{~b}$ & $2.6 \mathrm{~B} \mathrm{a}$ & $3.9 \mathrm{~B} \mathrm{~b}$ \\
\hline $30-40$ & 1.7 BC ac & $2.2 \mathrm{~B} \mathrm{a}$ & $4.0 \mathrm{~B} \mathrm{~b}$ & $2.8 \mathrm{~B} \mathrm{c}$ & $4.0 \mathrm{~B} \mathrm{~b}$ \\
\hline \multicolumn{6}{|c|}{$\mathrm{Cu}$} \\
\hline $00-10$ & $22.0 \mathrm{~A} \mathrm{a}$ & $25.7 \mathrm{~A} \mathrm{~b}$ & $25.2 \mathrm{~A} \mathrm{~b}$ & $27.5 \mathrm{~A} \mathrm{bc}$ & $28.5 \mathrm{~A} \mathrm{c}$ \\
\hline $10-20$ & $20.2 \mathrm{~A} \mathrm{a}$ & $19.0 \mathrm{~B} \mathrm{a}$ & $23.2 \mathrm{AB} \mathrm{b}$ & $25.2 \mathrm{~A} \mathrm{bc}$ & $27.0 \mathrm{~A} \mathrm{c}$ \\
\hline $20-30$ & $18.2 \mathrm{~B} \mathrm{ac}$ & $16.7 \mathrm{~B} \mathrm{a}$ & $22.7 \mathrm{~B} \mathrm{bc}$ & $20.0 \mathrm{~B} \mathrm{c}$ & $25.5 \mathrm{AC} \mathrm{d}$ \\
\hline $30-40$ & $15.5 \mathrm{~B} \mathrm{a}$ & $9.2 \mathrm{C} \mathrm{b}$ & $17.5 \mathrm{C} \mathrm{a}$ & $15.5 \mathrm{~B} \mathrm{a}$ & $23.2 \mathrm{C} \mathrm{c}$ \\
\hline
\end{tabular}

avalues within a row followed by different lower case letters are significantly different (LSD $\mathrm{p} \leq 0.05$ ).

${ }^{b}$ Values within a column followed by different upper case letters are significantly different (LSD $p \leq 0.05$ ).

Micronutrients (Table 3)

According to Lindsay and Norvell (1978) the critical levels for $\mathrm{Fe}, \mathrm{Zn}, \mathrm{Mn}$, and $\mathrm{Cu}$ are 4.0-5.0, $0.5-1.0,1.0-5.0$, and $0.1-2.5$ ppm respectively.

Checking the results for iron it can be seen that in all treatments a strict stratification for lower values is evident with increasing depth. Especially in $\mathrm{C}$ the Fe values fall below the critical levels in the layers $20-40 \mathrm{~cm}$. In all other variants $\mathrm{Fe}$ is sufficient in all tested layers. A horizontal comparison shows that $\mathrm{PG}$ and $\mathrm{NG}$ have significant higher values than the remaining treatments. This is a result of the grass stands which will solubilize Fe. Responsible is the proton extrusion of their dense root system which will finally decrease the soil's pH (Table 1).

Grapevines are very susceptible to iron deficiency especially when rootstock and scion do not fit exactly in the growing site; this can be often overcome installing a permanent grass cover which will increase the Fe availability for grapevines.
Zinc shows a similar behavior like Fe: in every variant exists a distinct and significant decrease of $\mathrm{Zn}$ concentrations with increasing soil depth. In none of the cases the critical levels are reached. The vertical comparison shows that in the upper layer all treatments, except C, have higher Zn levels. In contrast to Fe the grass stands do not exert such a pronounced influence on the availability of $\mathrm{Zn}$.

Manganese seems to be a critical microelement in that vineyard site. The critical level is exceeded only in the upper layer of PG, NG. In IC the overpass is not really given; it's more or less critical. The same situation exists, which has been found for Fe and $\mathrm{Zn}$ with a pronounced stratification with soil depth. In all cases the nutritional status for $\mathrm{Mn}$ is critical for grapevines.

Copper exerts a complete different image. In all tested soil layers and in the treatments is enough available $\mathrm{Cu}$ for the plant. There is a tendency that in the upper layer in EC and IC the $\mathrm{Cu}$ content is higher than in PG and NG. The distribution of the copper contents allows the supposition that in 
Tab. 4: Influence of different tillage systems on different soil enzymes' activity (nmole nitrophenol $\mathrm{x} \mathrm{g}^{-1} \mathrm{xh}^{-1}$ )

\begin{tabular}{|c|c|c|c|c|c|}
\hline Soil depth (cm) & $\begin{array}{l}\text { Control } \\
\text { [C] }\end{array}$ & $\begin{array}{c}\text { Grass sod } \\
{[\mathrm{PG}]}\end{array}$ & $\begin{array}{c}\text { Natural grass sod } \\
{[\mathrm{NG}]}\end{array}$ & $\begin{array}{c}\text { Extensive cultivation } \\
{[\mathrm{EC}]}\end{array}$ & $\begin{array}{c}\text { Intensive shallow } \\
\text { [IC] }\end{array}$ \\
\hline \multicolumn{6}{|c|}{$\alpha$-glucosidase } \\
\hline $00-10$ & $384 A^{a} a^{b}$ & $590 \mathrm{~A} \mathrm{~b}$ & $432 \mathrm{~A} \mathrm{a}$ & $445 \mathrm{~A} \mathrm{a}$ & $379 \mathrm{~A} \mathrm{a}$ \\
\hline $10-20$ & $243 \mathrm{~B} \mathrm{a}$ & $309 \mathrm{~B} \mathrm{~b}$ & $258 \mathrm{~B} \mathrm{a}$ & $303 \mathrm{~B} \mathrm{~b}$ & $226 \mathrm{~B} \mathrm{a}$ \\
\hline $20-30$ & $166 \mathrm{BC} \mathrm{a}$ & $256 \mathrm{BC} \mathrm{b}$ & $222 \mathrm{~B} \mathrm{c}$ & $214 \mathrm{C} \mathrm{c}$ & $186 \mathrm{Ba}$ \\
\hline $30-40$ & $142 \mathrm{C} \mathrm{a}$ & $210 \mathrm{Cb}$ & $182 \mathrm{~B} \mathrm{c}$ & $166 \mathrm{C} \mathrm{c}$ & $169 \mathrm{~B} \mathrm{c}$ \\
\hline \multicolumn{6}{|c|}{$\beta$-glucosidase } \\
\hline $00-10$ & $2492 \mathrm{~A} \mathrm{a}$ & $3335 \mathrm{~A} \mathrm{~b}$ & $2842 \mathrm{~A}$ ac & $2885 \mathrm{~A}$ ac & $2172 \mathrm{~A}$ ad \\
\hline $10-20$ & $1135 \mathrm{~B} \mathrm{a}$ & $1112 \mathrm{~B} \mathrm{a}$ & $1065 \mathrm{~B} \mathrm{a}$ & $1155 \mathrm{~B} \mathrm{a}$ & 857 B b \\
\hline $20-30$ & $727 \mathrm{~B} \mathrm{a}$ & $937 \mathrm{~B} \mathrm{~b}$ & $865 \mathrm{~B} \mathrm{~b}$ & $755 \mathrm{~B} \mathrm{a}$ & $642 \mathrm{~B} \mathrm{a}$ \\
\hline $30-40$ & $580 \mathrm{~B} \mathrm{a}$ & $680 \mathrm{~B} \mathrm{~b}$ & $712 \mathrm{~B} \mathrm{~b}$ & $555 \mathrm{~B} \mathrm{a}$ & $537 \mathrm{~B} \mathrm{a}$ \\
\hline \multicolumn{6}{|c|}{ neutral phosphatase } \\
\hline $00-10$ & $847 \mathrm{~A} \mathrm{~b}$ & $3600 \mathrm{~A} \mathrm{a}$ & $1840 \mathrm{~A} \mathrm{~b}$ & $1037 \mathrm{~A} \mathrm{~b}$ & $877 \mathrm{~A} \mathrm{~b}$ \\
\hline $10-20$ & $752 \mathrm{~B} \mathrm{~b}$ & $957 \mathrm{~B} \mathrm{a}$ & $777 \mathrm{~B} \mathrm{~b}$ & $760 \mathrm{~B} \mathrm{~b}$ & $645 \mathrm{~B} \mathrm{c}$ \\
\hline $20-30$ & $737 \mathrm{~B} \mathrm{ac}$ & $795 \mathrm{~B} \mathrm{a}$ & $690 \mathrm{~B} \mathrm{C}$ & $657 \mathrm{~B} \mathrm{c}$ & $550 \mathrm{BC} \mathrm{d}$ \\
\hline $30-40$ & $655 \mathrm{C} \mathrm{a}$ & $725 \mathrm{~B} \mathrm{a}$ & $522 \mathrm{~B} \mathrm{~b}$ & $525 \mathrm{C} \mathrm{b}$ & $492 \mathrm{C} \mathrm{b}$ \\
\hline \multicolumn{6}{|c|}{ alkaline phosphatase } \\
\hline $00-10$ & $3647 \mathrm{~A} \mathrm{a}$ & $6137 \mathrm{~A} \mathrm{bc}$ & $6427 \mathrm{~A} \mathrm{~b}$ & $5132 \mathrm{~A} \mathrm{c}$ & $3305 \mathrm{~A} \mathrm{a}$ \\
\hline $10-20$ & $3082 \mathrm{~B} \mathrm{a}$ & 4545 B b & $3190 \mathrm{~B} \mathrm{a}$ & $3117 \mathrm{Ba}$ & $2410 \mathrm{BC}$ a \\
\hline $20-30$ & $2872 \mathrm{BC}$ a & 3997 B b & $2637 \mathrm{~B} \mathrm{ac}$ & $2625 \mathrm{~B} \mathrm{a}$ & 1977 B c \\
\hline $30-40$ & $2545 \mathrm{C} \mathrm{ac}$ & $3850 \mathrm{~B} \mathrm{~b}$ & $2285 \mathrm{~B} \mathrm{a}$ & $2060 \mathrm{~B} \mathrm{a}$ & $1682 \mathrm{C} \mathrm{a}$ \\
\hline \multicolumn{6}{|c|}{ urease $\left(\right.$ nmole urea $\left.\times \mathrm{g}^{-1} \times \mathrm{h}^{-1}\right)$} \\
\hline $00-10$ & $689 \mathrm{~A} \mathrm{a}$ & $863 \mathrm{Ab}$ & $1003 \mathrm{~A} \mathrm{~b}$ & $859 \mathrm{~A} \mathrm{~b}$ & $543 \mathrm{~A} \mathrm{a}$ \\
\hline $10-20$ & $503 \mathrm{AC} \mathrm{a}$ & $587 \mathrm{~B} \mathrm{a}$ & $531 \mathrm{~B} \mathrm{ab}$ & $544 \mathrm{~B}$ ab & $378 \mathrm{~B} \mathrm{c}$ \\
\hline $20-30$ & $402 \mathrm{BC}$ a & $517 \mathrm{~B} \mathrm{~b}$ & $478 \mathrm{~B} \mathrm{c}$ & $540 \mathrm{~B} \mathrm{~b}$ & $386 \mathrm{~B} \mathrm{a}$ \\
\hline $30-40$ & $372 \mathrm{~B} \mathrm{a}$ & $515 \mathrm{~B} \mathrm{~b}$ & $475 \mathrm{~B} \mathrm{bc}$ & $414 \mathrm{~B} \mathrm{C}$ & $350 \mathrm{~B} \mathrm{c}$ \\
\hline
\end{tabular}

बalues within a row followed by different lower case letters are significantly different (LSD $\mathrm{p} \leq 0.05$ ).

${ }^{b}$ Values within a column followed by different upper case letters are significantly different (LSD $p \leq 0.05$ ).

the past heavy $\mathrm{Cu}$ applications were done against downy mildew. Leaf material was mixed with the soil and spray residues were also incorporated. Deep ploughing before the re-establishment of a vineyard which was done ca. every 20th year led to this unclear $\mathrm{Cu}$ distribution which is currently found. In case of a strong mobilization of this heavy metal all sorts of interactions between micronutrients may occur.

\section{Soil enzyme activities}

The enzymatic activity in the soil is mainly of microbial origin, being derived from intracellular, cell-associated or free enzymes. A distinct balance of chemical, physical, and biological (including microbial enzyme activities) components contribute to soil health. Evaluation of soil health therefore requires indicators of all these components. Healthy soils are essential for the integrity of terrestrial ecosystems to remain intact or to recover from disturbances, such as drought, climate change, pest infestation, pollution, and human exploitation including agriculture (Ellert et al., 1997). Soil enzymes play an important role in maintaining soil ecology, chemical properties and soil health. They have key functions in organic matter decomposition and buildup of stable humus matter (Sinsabaugh et al., 1991).

In our investigations $\alpha$-glucosidase and $\beta$-glucosidase, neutral and alkaline phosphatase, and urease (Table 4) were analyzed representative for the soils' $\mathrm{C}-, \mathrm{P}-$, and $\mathrm{N}$-cycle. 
For all tested enzymes it can be demonstrated that highest activities are found in the upper two layers with a strong tendency to a decrease with increasing depth. In most cases the lesser activities are significant on a level $\mathrm{p} \leq 0.05$. Comparing the enzyme activities horizontally the following results can be demonstrated.

$\underline{\alpha-g l u c o s i d a s e}$ is always the highest in PG and in all 4 tested layers. This indicates that the grass sod releases a lot of carbonaceous material via root debris which induces the formation of decaying enzymes. It can also be seen that the less mechanical tillage is exerted on the soil the higher seem the activities of glucosidases: $\mathrm{PG}>\mathrm{NG} \geq \mathrm{EC}$ $>\mathrm{C}$.

$\beta$-glucosidase activity is higher (5-6 times) than the $\alpha$-glucosidase indicating that greater amounts of cellulosic material is released and degraded in the soil. In the upper layer PG; NG and EC have highest activities. In the second one (10-20 cm), no differences exist except IC which is significantly lower. In the next two layers (2030 and $30-40 \mathrm{~cm}$ ) PG and NG show again higher activities. It seems that the higher input of organic debris via the root system is responsible for this enzyme distribution.

Neutral and alkaline phosphatases are the types which will dominate at the prevailing soil $\mathrm{pH}$ (Table 1). As stated for glucosidases also phosphatases show in all treatments a strict and significant stratification with soil depth (Table 4).

In comparison to $C$ and IC the treatments $P G$, NG and EC show phosphatase activities more than doubled. Alkaline phosphatase in contrast to the neutral one is 2 to 6 times higher depending on treatment and soil layer. In the tilled systems (EC and IC) the increase is not so pronounced. In the deeper layers activities of both enzymes reduce more or less sharply but the influence of grass in PG (higher organic residues) is always significant.

Urease activity (Table 4) shows also in all treatments a decrease with increasing soil depth. The upper layer is always significantly different from the remaining ones. The horizontal comparison shows that $\mathrm{PG}, \mathrm{NG}$, and $\mathrm{EC}$ have higher urease activities in all soil depths than $\mathrm{C}$ and IC. These results show that soil tillage systems exert specific effects on the nutrient dynamic in soils. On one hand, it can be seen that specially chosen system may improve the amounts of available macro- and micro- nutrients and, on the other hand soil enzymes can contribute to a higher level of diverse nutrients and can also improve C-storage.

\section{CONCLUSION}

Numerous studies exist about soil tillage and tillage systems describing their advantages and their pitfalls. Well-known textbooks describe all the possibilities for sound production and how to take care for the soil (Wild, 1988). Allison's monograph (1973) about soil organic matter gives a complex and complete overview about this important topic. In the late sixties McLaren and Peterson (1967) began to publish a book series on soil biochemistry and ten years later Burns (1978) edited his book about soil enzymes. These ideas form a basis to see soils, soil fertility and quality in a new light. Especially the environmental services are most important.

Research in soil fertility is the more reliable the longer the test fields are observed. Good examples are the Rothamsted experiment in Great Britain and the "Statische Düngungsversuch in Bad Lauchstädt" (Körschens, 1994). Both have duration of more than hundred years. In viticulture those experiments are very rare because this culture was (and is) mostly carried out on marginal agricultural land where questions about soil fertility were not in the foreground. Usually measures to prevent soil losses were in the focus but not the concept of soil quality. Our experiment which lasted approx. 20 years may be therefore a milestone in soil fertility research in viticulture.

In this field test 5 typical soil tillage systems were tested: Control (tilling operations as commonly used), permanent grass cover with English ray grass and white clover, marginal grassland, extensive tilling and intensive shallow tilling. It was demonstrated that permanent grass sod and marginal grassland have a lot of advantages over conventional tilling systems. Concerning soil nutrients and their availability, the systems with grass components, regardless of more intense or marginal improve the nutrient status. Most important is that especially the imbalances between $\mathrm{K}$ and $\mathrm{Mg}$ are corrected and physiological disorders in grapevines can be prevented. In addition micro-nutrients get more soluble. That is important for $\mathrm{Fe}$ and $\mathrm{Mn}$ in calcareous soils.

Concerning general fertility aspects it could be concluded that the C-content of the soil can be 
increased on a long term. Neither in the control plots nor in the tilled ones was it possible to enrich the natural C-content. Tilling operations favor more or less the decay of organic material. In the permanent grass plot it was possible to achieve an annual $\mathrm{C}$ buildup in a range of approx. $0.117 \mathrm{~kg} \mathrm{C} \mathrm{x}$ $\mathrm{m}^{-2} \mathrm{xa}^{-1}$ which corresponds to $3.3 \mathrm{tCO}_{2} \mathrm{x} \mathrm{ha}^{-1} \mathrm{x} \mathrm{a}^{-1}$.

This may be a valuable contribution of viticulture to climatic safe grapevine growing system. For the near future we need more research on this topic in different environments to improve viticulture to climate friendly plant production system.

\section{REFERENCES}

1. Allison FE (1973). Soil Organic Matter and its Role in Crop Production. Developments in Soil Science Vol. 3. Elsevier Scientific Publishing Company, Amsterdam, New York.

2. Bremner JM and Douglas LA (1971). Inhibition of urease activity in soils. Soil Biol. Biochem 3:297-307.

3. Burns RG (1978). Soil Enzymes. Academic Press, LondonNew York-San Francisco

4. Dick RP (1992). A review: Long term effects of agricultural systems on soil biochemical and microbial parameters. Agric. Ecosyst. Environ. 40:25-36.

5. Ellert BH, Clapperton M J, Anderson DW (1997). An ecosystem perspective of soil quality. In: Gregorich, E.G., Carter, M.R. (eds) Soil quality for crop production and ecosystem health. Elsevier, Amsterdam, pp 115-141.
6. Hayano K (1973). A method for the determination of $\beta$-glucosidase activity in soil. Soil Sci. Pl. Nutr. 19:103-108.

7. Körschens M (Hrsg.) (1994). Der statische Düngungsversuch Bad Lauchstädt nach 90 Jahren. B.G. Teubners Verlagsgesellschaft Stuttgart Leipzig.

8. Lindsay WL and Norvell WA (1978). Development of a DTPA soil test for zinc, iron manganese, and copper. Soil Sci. Soc. Am. J. 42: 421-428.

9. McLaren AD and Peterson GH (1967). Soil Biochemistry. Marcel Dekker Inc. New York

10. Sinsabaugh RL, Antibus RK, Linkins AE (1991). An enzymic approach to the analysis of microbial activity during plant litter decomposition. Agric. Ecosyst. Environ. 34:43-54.

11. Steinberg B (1979). Begrünung im Weinbau. Der Deutsche Weinbau Heft 14:759-767.

12. Tabatabai MA and Bremner JM (1969). Use of p-nitrophenyl phosphate for assay of soil phosphatase activity. Soil Biol. Biochem. 1:301-307.

13. VDLUFA-Methodenbuch. Bd. 1: Die Untersuchung von Böden. ISBN 978-3-941273-13-9.

14. Warkentin BP (1995). The changing concept of soil quality. J. Soil Water Conserv. 50:226-228.

15. Wienhaus H (1981). Der Rohrschwingel, eine bei Begrünungsvorhaben im Obst- und Weinbau meist übersehene trockenresistente Grasart. Z. f. Vegetationstechnik 4:141-144.

16. Wild A (1988). Russell's Soil Conditions and Plant Growth. 11th ed. Longman Scientific \& Technical, Essex, England. 